\title{
Corporeidades no catolicismo brasileiro
}

\author{
Murilo Eduardo Nazario'
}

\section{RESUMO}

Quando discutido para além dos determinismos biofisiológicos, o corpo mostra-se um objeto valioso de estudo, embora ainda sejam discretas ações a esse respeito. Com isso, indaga-se quais são as constituições corporais estabelecidadas pelo catolicismo brasileiro, uma vez que as religiões possuem em seu amálgama a busca pela organização da experiência nômica humana por meio da oferta e da difusão de estruturas de legitimação e plausibilidade, que constroem um cosmo coeso. Para tanto, foi realizada uma pesquisa de bases etnográficas com os católicos da comunidade tricentenária de Brumal (MG), buscando-se observar as diferentes constituições corporais e os diferentes usos do corpo durante as manifestações dessa comunidade de fé. Do mesmo modo, procedeu-se a seis entrevistas com moradores da localidade, maiores de 18 anos e de ambos os sexos. Nessa perspectiva, constatou-se que o corpo em movimento assume, nos diferentes momentos instituídos por tal solução sacral, maneiras de o católico viver e se situar em relação ao sagrado.

Palavras-chave: Corpo humano. Relações metafisicas mente-corpo. Catolicismo

1 Mestre em Ciências da Motricidade Humana. Professor Adjunto curso de Eduação Fìsica da Universidade Vila Velha (UVV) e Doutorando do Programa de Pos Graduação em Educação Física da Universidade Federal do Espírito Santo (PPGEF/UFES).Vila Velha/ Espírito Santo, Brasil. E-mail: murilo_nazario@hotmail.com 


\title{
Body techiniques for brazilian catholic
}

\begin{abstract}
The body when discussed beyond of biophysiological determinisms, shown to be a valuable object of study, however such actions are still discrete.With this, one inquires what are the corporal constitutions established by the Brazilian Catholicism? Since religions have in their almagama the search for the organization of human nomadic experience through the supply and diffusion of structures of legitimacy and plausibility, which construct a cohesive cosmos. In order to do so, a study of ethnographic foundations was carried out with the Catholics of the Brical community of Brumal (MG), seeking to observe the different body constitutions and different uses of the body during the manifestations of that community of faith. In the same way, we conducted six interviews with residents of the locality, over eighteen years of age and of both sexes. Therefore, the moving body assumes in different moments imposed by this solution sacral, ways of living and Catholic is located in relation to the sacred.
\end{abstract}

Keywords: Human body. Mind-body relations methaphysical. Catholicism

\section{Corporalidades en el catolicismo brasileño}

\section{RESUMEN}

Cuando discutido más allá de determinismo biofisiológico, el cuerpo demuestra ser un objeto valioso de estudio, aunque todavía son acciones discretas en este sentido. Por lo tanto, se pregunta, cuáles son las constituciones corporales estabelecidadas por el catolicismo brasileño? Dado que las religiones tienen en su almagama la búsqueda de la organización de la experiencia humana nómica a través del suministro y la difusión de las estructuras de legitimidad y de la verosimilitud, la construcción de un cosmos cohesivos. Para ello, se llevó a cabo un estudio de las bases etnográficas con los católicos de la comunidad tricentenária Brumal (MG), tratando de observar las diferentes constituciones corporales y diferente cuerpo utiliza durante las manifestaciones de que la comunidad de fe. Del mismo modo, se realizaron seis entrevistas con los residentes locales, mayores de dieciocho años y de ambos sexos. Desde esta perspectiva, se encontró que el móvil recorre diferentes tiempos establecidos por dicha solución sacra, formas católicas de vida y se encuentra en relación con lo sagrado.

Palabras clave: Cuerpo humano. Relaciones metafisica mente-cuerpo. Catolicismo 


\section{INTRODUÇÃO}

Quando Marcel Mauss, no início do século XX, propôs o conceito de Técnicas Corporais $^{2}$ no intuito de retirar o corpo da categoria de diversos, no campo das Ciências Sociais, ele possibilitou a ampliação das veredas investigativas que envolvem esse elemento, singularmente humano, contribuindo inclusive para as reflexões e discussões que permeiam o campo da Educação Física. Contudo, ainda são discretos os estudos que abordem o corpo como uma construção social, cultural e histórica. Para Albuquerque (2001, p.01), "o corpo pode e tem sido objeto de simbolizações como o demonstram os estudos sobre inscrições rituais, estigmas, racismos e etc. Apesar disso, não se observou, até recentemente, um interesse sociológico pelas questões corporais".

Embora outros estudos dentro da própria Educação Física tenham buscado considerar as nuances corporais para além do biofisiológico, mesmo de modo secundário, destaco aqui as obras de Daolio (2004), Soares et al. (1992), Betti (1991), Kunz (1994) e Bracht (1992). Todavia, há de se salientar que elas têm forte direcionamento para o campo de atuação escolar, com base nas teorias da Cultura de Movimento ou do "Se-movimentar", não sendo o enfoque desta pesquisa. Entretanto, esses empreendimentos científicos possibilitam a percepção e interpretação do corpo também como uma construção sociocultural, fornecendo indicativos significativos para este estudo.

Daolio (1995; 2004), em diálogo com referenciais da antropologia cultural, tem sinalizado as representações assumidas pelo corpo no contexto da Educação Física expresso por uma série de adjetivos, tais como belo, esbelto, saudável, sarado, bonito, firme, flácido, gordo, magro, franzino, holístico. Nesse sentido, o autor situa a reflexão sobre a atuação profissional dessa área no trato que envolve o ser humano acerca/através do seu corpo. Embora para isso seja necessário retomar a fronteira que envolve o natural e o cultural, ao assumir essa última perspectiva, deve-se inserir o ser humano numa dinâmica cultural, cujos contornos específicos estão em consonância com determinado grupo social e o tempo sócio-histórico ao qual pertence.

À vista disso, o corpo não é somente uma articulação de órgãos arranjados segundo leis da anatomia e da fisiologia. É, em primeiro lugar, uma estrutura simbólica, superfície de projeção possível de unir as mais variadas formas culturais" (LE BRETON, 2007, p. 29). Esse corpo também representa um patrimônio singular da humanidade que extrapola os determinismos biológicos e as semelhanças e as diferenças físicas e é permeado por diferentes significados que as diferentes sociedades definem (DAOLIO, 2004).

Com isso, o corpo pode ser entendido como "o primeiro e o mais natural instrumento do homem. O mais exatamente, sem falar de instrumento o primeiro e mais natural objeto técnico, e ao mesmo tempo o meio técnico do homem é seu corpo" (MAUSS, 1974, p. 217).

A condição corporal, quando percebida na articulação entre o individual e o coletivo, é recheada de significações, experimentações e fatos do imaginário social.

2 “ $\{\ldots\}$ são as maneiras como os homens sociedade por sociedade e de maneira tradicional fazem uso de seus corpos" (MAUSS, 1936, p. 211). 


\begin{abstract}
Estes, por sua vez, atuam em um processo educacional que molda o indivíduo e as representações assumidas por suas corporeidades, tornando-o um duplo agente acional, por ser tanto um emissor quanto um receptor de sentidos, dentro de um espaço e de um tempo social. Assim, o corpo torna-se para o ser humano um vetor semântico que permite fazer do mundo coletivo, que o envolve, a extensão de sua própria experiência (LE BRETON, 2007).
\end{abstract}

Nessa perspectiva, entre os diferentes caminhos possíveis para discutir a constituição corporal nessa interface com o cultural, este estudo explora aquele relacionado à construção de corporeidades pelo campo religioso, em específico, no subcampo do catolicismo. Esses pressupostos podem ser entendidos como conexões para o pensar epistemológico da Educação Fìsica, cujo objeto de investigação está acentado no entendimento, ensino e compartilhamento das práticas corporais, nas quais o corpo assume a condição de receptor e emissor de signos sociais da sociedade pertencida, expressos por meio das brincadeiras, esportes, ginásticas e/ou das ações técnicas requeridas por essas manifestações.

Especificamente, sobre as reflexões que norteiam nosso estudo, é possível verificar na própria obra de Marcel Mauss menções, mesmo que discretas, da relação entre o religioso e o corpóreo, como no trecho: "o ato técnico, ato físico, ato mágico religioso, são confundidos pelo agente"(MAUSS, 1974, p. 217). Em contrapartida, são carentes os estudos específicos sobre as relações entre a religião católica brasileira e a constituição de corporeidades, visto que as religiões podem ser entendidas como "edifícios de conhecimento que compreendem tabus, proibições, interditos e legitimações coletivas dos usos do corpo que conferem identidade religiosa aos seus seguidores" (BIANCONI, 2008, p. 1).

Por outro lado, quando as discussões permeiam o contexto do Cristianismo ${ }^{3}$ em suas bases gerais, é possível verificar que o corpo tem sido objeto de discussões, pois tudo passaria por ele, ou como nas palavras de Gelis (2008, p. 19), “(...) fizeram do corpo um sujeito na história". Ainda para o autor, as condições que o elevaram a esse patamar estão centradas na figura de Jesus e desdobradas nestes diferentes momentos:

Corpo de Cristo que comemos que se revela a partir do real e da carne. Pão que converte e salva os corpos. Corpo magnificado do Filho encarnado, do encontro do Verbo com a Carne. Corpo glorioso do Cristo da Ressurreição. Corpo torturado do Cristo da Paixão cujo símbolo é em toda a cruz, lembra o sacrifício pela redenção da humanidade. Corpo em migalhas da grande Legião dos santos. Corpo maravilhoso dos eleitos no juízo final (GELIS, 2008, p. 19).

Nesse sentido:

É preciso lembrar que, para historiadores da antiguidade tardia, a grande transformação operada no campo do sagrado pelo cristianismo foi colocar o homem - o corpo do homem, o mártir, a relíquia, o santo, a história feita lembrança de uma existência

3 Referimo-nos ao Cristianismo antes da reforma protestante. 
testemunhada num corpo de homem - no lugar da natureza. Substituiu o sagrado cósmico pelo homem e o seu destino histórico (SANCHIS, 2000, p. 10).

Maues (2000), por exemplo, investigou como as técnicas corporais são expressas em uma das expressões do catolicismo: a Renovação Carismática. Nesse empreendimento, ele encontra como resultados principais o toque corporal, a imposição de mãos, a dança, a glossolalia e o repouso no espírito. Ele percebe que essas técnicas tanto possuem variações de acordo com o ritual realizado quanto podem variar entre os diferentes momentos de um mesmo ritual. Assim, o toque corporal apresenta-se no aperto de mãos, no abraço, na imposição das mãos, palmas das mãos para cima e para fora, no bater de palmas e nos aplausos. Já a dança possui coreografias que variam de acordo com o momento em que está a celebração. A glossolalia também é fator decisivo para elevar o carismático ao êxtase, ou a um estado alterado de consciência, envolvendo os sentidos corporais de maneira substancial. De modo geral, fica evidente a condição de destaque assumida pelo corpo no Movimento de Renovação Carismática, pois é a partir dele que se estabelece a experiência significativa com a divindade.

Sendo assim, neste estudo apoiado em perspectivas da Educação Física em suas dimensões que não se esgotam na discussão biológica, nasce a seguinte questão: quais sãos constituições corporais estabelecidas pelo catolicismo brasileiro? Com isso, espera-se analisar e discutir como o corpo se expressa e está configurado no/pelo campo religioso católico brasileiro. Para isso, é necessário inverter o olhar costumeiro das investigações em Educação Física, ou seja, antes de pensar a ação pedagógica escolar, ou as vertentes do treinamento esportivo, ou mesmo do lazer, deve-se considerar o corpo em movimento como uma construção social anterior a esses espaços institucionalizados. Ou seja, antes de estar nesses campos, onde há a presença do profissional de Educação Física, o sujeito e seu corpo são instâncias que estabelecem e sofrem relações de confluência da dinâmica cotidiana sociocultural.

\section{MATERIAL E MÉTODOS}

O ponto de partida da vereda metodológica assumida por esta pesquisa organiza-se em torno de pressupostos básicos das religiões, o de legitimar e organizar a experiência existencial humana. Cada cosmologia estrutura e configura um nomos com particularidades que lhe são características. Desse modo, este estudo optou por organizar o seu empreendimento investigativo para com o catolicismo na esfera brasileira e as manifestações corporais que o indivíduo católico performatiza. Para Camargo (1973), o catolicismo brasileiro deve ser entendido para além de suas doutrinas e crenças ortodoxas e como uma construção cultural, social e histórica, possuidora de singularidades expressas em suas caracterizações, ações, apropriações, valores, símbolos, além do entrelace com estruturas sociais, como estado, economia e mudança social. 
Desse modo, as religiões - e com o catolicismo não é diferente - realizam o empreendimento de organização da experiência nômica humana por meio da oferta e da difusão de estruturas de legitimação e plausibilidade, que são interiorizadas pelos fiéis, possibilitando-lhes desenvolver uma cosmovisão religiosa. Esse processo de interiorização fica mais bem entendido com base no conceito de habitus.

Bourdieu (2004) apresenta várias condições e necessidades geradoras do elemento habitus, com certo destaque para o que ele denomina campo ${ }^{4}$. O autor considera a existência de vários campos, entre os quais o científico, o intelectual, o econômico e o religioso. Dentro do campo religioso, configuram-se outros subcampos representandos pelas inúmeras soluções sacrais e os respectivos atores, padres, pastores, curandeiros, gurus e profetas, que concorrem entre si no mercado de bens de salvação, para tanto impor o religioso quanto ser o religioso. Assim, conceitos, nomenclaturas e tipologias são tentativas de classificar as diferentes expressões católicas brasileiras. Ao realizar esse empreendimento reflexivo, é possível perceber as seguintes tipologias: catolicismo rural, catolicismo tradicional urbano, catolicismo internalizado rural e catolicismo internalizado urbano (CAMARGO, 1973).

Para complementar essa explanação:

O habitus é ao mesmo tempo um sistema de esquemas de produção de práticas e um sistema de esquemas de percepção e apreciação das práticas. E, nos dois casos, suas operações exprimem a posição social em que foi construído. Em consequência, o habitus produz práticas e representações que estão disponíveis para a classificação, que são objetivamente diferenciadas (...). (BOURDIEU, 2004 p. 158).

Por outro lado, Elias (1994) encontra, no conceito habitus social, a possibilidade de discutir a inter-relação entre indivíduo e sociedade de maneira integral, sem a ruptura de distinção que ocasionalmente ocorre. Ao realizar tal procedimento, o autor consegue articular diferentes elementos da máxima balança nós-eu, entre os quais as questões de nação, tradição e transmissão cultural, para elencar os diferentes processos configurativos estabelecidos dessa relação nem sempre harmoniosa entre indivíduo e sociedade. As implicações desse conceito nos fornecem subsídios para direcionar a perspectiva do habitus para o âmbito católico da comunidade pesquisada, uma vez que o exterior coletivo são as configurações, as estruturas e os elementos que envolvem e caracterizam tal cosmo. Já a perspectiva de interiorização é o modo como tais configurações, elementos e estruturas acabam por se inscrever no indivíduo católico e, consequentemente, orientar a sua maneira de ser perante o religioso e o contexto social a sua volta. No presente caso, dedicamo-nos às expressões corporais provocadas por essa interiorização particular da cosmologia católica.

Do mesmo modo, é possível inferir que a prática católica possui apropriações singulares que estão relacionadas às diferentes localidades e regiões brasileiras que oportunizam experiências singulares com o inefável sagrado, naquilo que tange tal solução

4 Para Bourdieu (2004, p. 119), o termo designa "um espaço - o que eu chamaria de campo - no interior do qual há uma luta pela imposição da definição do jogo e dos trunfos necessários para dominar nesse jogo". 
sacral. Todavia, é preciso ainda dizer que, mesmo numa determinada religião, existem particularidades quanto aos níveis de adesão e participação comunitária ante o sagrado, aspecto fundamental para compreender a constituição do habitus católico. Com isso, seria pretensão demais pressupor que o estudo de uma determinada comunidade possa fornecer as bases de compreensão unitária do catolicismo como um todo no Brasil. E o inverso também deve ser considerado, visto que as particularidades de um lugar não desconsideram as estruturas gerais da ortodoxia católica.

Sendo assim, como um xamã solitário em sua viagem vertical (para dentro e para cima), o pesquisador deve assumir as bases fundamentais da etnologia. No entanto, ele também não deve ignorar o antrophological blues, que, em outras palavras, também representa a junção do que está legitimado pelos manuais, com os aspectos extraordinários do viver humano que não estão escritos em nenhum documento (DA MATTA, 1978). Ao mencionarmos a perspectiva da viagem xamânica nos estudos etnológicos, fazemo-lo por meio de uma analogia aos ensinamentos do Xamã Dom Juan, da tribo mexicana dos Yaqui, a Carlos Castañeda. Todavia, pela grandeza que cerca a obra mencionada, destacamos o estado de alerta e enfrentamento que o homem, em busca de conhecimento, deve realizar para com seus quatro inimigos naturais: medo, clareza, poder e velhice (CASTAÑEDA, 1968).

Ao orgarnizarmos o empreendimento investigativo inspirado na experiência xamânica em consonância com as três fases que orientam uma pesquisa etnológica, chegamos à seguinte estruturação: o contato com as Ciências Sociais, as leituras da área sociocultural da Educação Física e as primeiras orientações representaram a fase teórioco-intelectual. Por meio delas, foi possível atingir a segunda fase, a da prática, ao identificarmos os diferentes catolicismos presentes no Brasil, para que assim tivéssemos suporte necessário para caracterizar as singularidades do praticado no distrito de Brumal-MG. Com isso, algumas questões começaram a ser respondidas, imagens ganharam formas, sensações ganharam sentidos e gestos ganharam significados. Porém, nesse ciclo inexato e inacabado do viver sociocultural humano, novas indagações surgiram, formando a terceira fase, aquela de caráter existencial e pessoal.

Ademais, conforme afirma Mills (1975, p. 14), "é por isso, em suma, que os homens esperam, hoje, perceber o que está acontecendo no mundo e compreender o que está acontecendo com eles, como minúsculos pontos de cruzamento entre a biografia e a história, dentro da sociedade".

Assim, foram sujeitos deste estudo adultos de ambos os sexos, praticantes do catolicismo em Brumal. Brumal é um distrito do município de Santa Bárbara-MG, situado na região central de Minas Gerais, ao pé da Serra do Caraça e a aproximadamente $90 \mathrm{~km}$ de Belo Horizonte, cuja fundação data de 1701. Sua principal fonte econômica é a mineração de ouro e de minério de ferro, que fornecem trabalho para boa parte da população adulta do lugar. Sua população está em torno de 1.100 pessoas, das quais 516 homens e 553 mulheres (ANGLOGOLD, 2009). Delineando as informações para o catolicismo na localidade, é possível constatar a predominância dessa manifestação religiosa com base no senso do Instituto de Geografia e Estatística (IBGE) de 2010, que forneceu os seguintes dados: a população total de Santa Bárbara em 2010 era de 27.485 moradores, dos quais 
22.193 se consideravam católicos apostólicos romanos, 4.319 evangélicos e 973 disseram não possuir religião. Não foi possível apresentar dados específicos do distrito devido à metodologia empregada pelo IBGE, que apresenta seus dados de maneira geral por município.

Brumal pertence politicamente ao município de Santa Bárbara, porém tem suas questões religiosas orientadas pela Arquidiocese do município de Mariana. Atualmente Brumal foi elevado à condição de Curato Nossa Senhora das Graças, pelo decreto de Dom Luciano Mendes de Almeida em 2006. Porém, o distrito somente alcançaria a autonomia jurídica, administrativa e financeira em 2010, ano da criação de seu CNPJ (Cadastro Nacional de Pessoa Jurídica) (SILVA, 2011). As principais ações religiosas em consonância com a participação leiga no distrito de Brumal relacionam-se às pastorais, ao coral, às catequeses, aos ministérios da comunhão, à Sociedade São Vicente de Paulo, à Irmandade do Santíssimo e à Legião de Maria (CURATO, 2011).

Dessa maneira, tivemos como ponto de partida os diferentes rituais e manifestações católicas em Brumal. Para tanto, foi realizado o procedimento de observação participante. Isso se deve à necessidade de interação entre o pesquisador e o pesquisado por tempo suficiente, para angariar as informações que extrapolam os aspectos superficiais apresentados pelo grupo (VELHO, 1978). Nesse sentido e com base nos pressupostos de estranhamento, distância e neutralidade, retomamos as questões que cercam a transformação do exótico em familiar e do familiar em exótico.

Para Velho (1978, p. 45):

Acredito que seja possível transcender, em determinados momentos, as limitações de origem do antropólogo e chegar a ver o familiar não necessariamente como exótico, mas como uma realidade bem mais complexa do que aquela representada pelos mapas e códigos básicos nacionais e de classe que fomos socializados. O processo de estranhar o familiar torna-se possível quando somos capazes de confrontar intelectualmente, e mesmo emocionalmente, diferentes versões e interpretações existentes a respeito de fatos, situações.

Com esses cuidados e após aprovação da pesquisa no Comitê de Ética da Unesp - Rio Claro, Parecer 031/12 e Protocolo 8.744, as observações seguiram o calendário litúrgico oficial, com início em janeiro e término em dezembro. Complementando a perspectiva estrutural e organizacional do tempo sociorreligioso de Brumal, articulamos as observações, no transcorrer dos sete sacramentos estabelecidos pelo cosmo católico durante esses doze meses. A inclusão dos sacramentos amplia a perspectiva sobre a função de orientar vidas que o catolicismo desempenha, pois eles marcam desde o ingresso do indivíduo no catolicismo, momento ritualizado pelo sacramento do batismo, até a morte ou a saída desse mesmo indivíduo, momento ritualizado pelo sacramento da unção dos enfermos, embora este não seja destinado exclusivamente a tal fim.

Ao término desta etapa, foram selecionados seis sujeitos católicos de Brumal, todos maiores de 18 anos, para a realização de uma entrevista, de natureza narrativa. Esse procedimento foi realizado no intuito de ampliar a captação de informações e indicadores empíricos sobre as maneiras como os indivíduos vivem e performatizam seus corpos em 
relação à experiência com o nomos sagrado católico. Do mesmo modo, permitiu analisar como as estruturas de legitimação e plausibilidades ofertadas por essa cosmologia se inscrevem em seus corpos. A participação desses sujeitos somente ocorreu após a devida aquiescência, dada por eles mediante o Termo de Consentimento Livre e Esclarecido.

Sobre a entrevista narrativa, cumpre dizer que é recomendada para estudos que combinem histórias de vida e contextos históricos, valorizando a trajetória do informante com a ideia básica de recontar uma história. Ela parte do pressuposto de que cada indivíduo traz consigo palavras e sentidos específicos relacionados à sua experiência vivida em comunidade, articulando os seus aspectos coletivos e individuais, fundamentais e característicos. A proposta fundamental da entrevista narrativa é construir acontecimentos sociais com base na perspectiva dos informantes, tão diretamente quanto possível (JOVCHELOVITCH e BAUER, 2002).

Em consonância com esse primeiro procedimento metodológico e com o nosso pensamento em fomentar as reflexões que envolviam a discussão analítica do estudo, articulamos os resultados das observações com aqueles levantados por meio das entrevistas. Com essa ação, foi possível ampliar as perspectivas que abrangem os níveis de representatividade que cercam essa religião na comunidade estudada. Em outras palavras, a articulação entre as observações e as entrevistas possibilitou a expansão de um dos conceitos-chave deste estudo: o de habitus. Essa condição somente é alcançada quando conseguimos articular a observação com o "dar" voz aos agentes envolvidos, no caso os católicos de Brumal. Esse aspecto também contribui para ampliar a construção de uma cosmovisão em uma cosmologia. Durante o desenrolar do estudo, a contribuição dos sujeitos foi transcrita por meio da seleção parcial ou integral de suas falas, as quais foram inseridas nas categorias de análise propostas.

\section{RESULTADOS E DISCUSSÃO}

Para melhor ordenamento dos resultados, foram estabelecidas quatro categorias de análise: corpo sacramental, corpo escatológico, corpo alimentar e técnicas corporais nas manifestações católicas em Brumal. Embora seja necessário apontar as mudanças ocorridas na esfera católica, destacamos aqui o Concílio Vaticano II, que reorganizou algumas bases eclesiásticas; uma delas, talvez a mais importante, fez do sacramento eucarístico o elemento central dos ditames e preceitos do catolicismo. Sendo assim, para melhor entendimento dessas categorias de análise, é fundamental perceber o sacramento eucarístico como eixo central e elemento comum entre elas.

Antes de prosseguir com a discussão, gostaria de apresentar um ponto em comum entre as categorias de análise estabelecidas (entre os sacramentos), referente ao espaço onde eles transcorrem. Isso, porém, não quer dizer que todos eles se desenvolvem no mesmo local. Para Eliade (1992), o espaço pelo prisma do sagrado não é homogêneo; em contrapartida, as perspectivas profanas consideram o espaço homogêneo. O homem religioso reconhece no espaço tido por sagrado o seu ponto de orientação e o seu eixo 
central para a construção de mundos e a organização de sua experiência humana. Assim, quando o indivíduo religioso, no caso o católico de Brumal, reconhece a existência de espaços religiosos, aqueles locais tornam-se uma hierofania, ou seja, o ponto de maior possibilidade de contato com o inefável sagrado.

Os sacramentos apresentam-se como elementos da tradição cristã, que comprovam a presença de Jesus na terra, ritualizados para realizar o contato entre o indivíduo e o sagrado (NUNES, 2008). Ao todo são reconhecidos sete sacramentos: batismo, crisma, eucaristia, ordem, unção aos enfermos, matrimônio e penitência. Na comosvisão católica, eles colaboram para organizar o viver humano, pois eles marcam o caminho percorrido pelo fiel até a salvação. Para isso, estão organizados nas datas do calendário religioso e em momentos-chave da vida. Assim, quando pensamos o viver humano em uma condição cronológica, desde o nascimento até a morte, o catolicismo apresenta, por meio de seus sacramentos, momentos ritualísticos de passagem e entrada. Desse modo, enquanto o sacramento do batismo marca a entrada do indivíduo no cosmo católico, o rito da extrema unção, não exclusivamente para esse fim, marca a sua saída/passagem para o mundo post mortem. Essas estruturas estão inscritas na cosmovisão católica local, como pode ser averiguado nos seguintes fragmentos:

Entrevistada 1: Bom, pra mim o batismo é como se estivesse entrado pra família de Jesus.

Entrevistada 3: Pra mim, eles significam a manifestação de Jesus, cada um pra lembrar a gente da passagem e da importância dele em nossa vida".

Entrevistado 6: Olha, Sacramento, eu entendo como um sinal. Vamos dizer assim, é um sinal pra gente seguir um caminho.

O batismo, na tradição católica, é o primeiro dos sacramentos e representa a entrada do indivíduo no cosmo cristão (NUNES, 2008). Dito de outro modo, o batismo assume a representação de ser o ponto de partida do caminho que o católico deve percorrer até atingir o estado de salvação. Isso pode ser sustentado com os seguintes dizeres de uma das entrevistadas: "Bom!? Pra mim é como se estivesse entrado pra família de Jesus". Isso fica nítido na narrativa apresentada pelo futuro padre de Brumal:

Diácono: Outra coisa, no batismo, ele tem que ser visto como a porta de entrada, porque nenhum dos outros seis sacramentos podem [sic] ser administrados sem o batismo.

Por outro lado, no imaginário católico, o batismo também representa a possibilidade de anular o pecado original que cada indivíduo traz consigo, devido a sua concepção pelo ato sexual. Para Le Goff (1994), Santo Agostinho ${ }^{5}$ foi o responsável pela difusão do nexo entre o pecado original e a sua transmissão pela concupiscência.

5 Por ser o primeiro teólogo - inserido no contexto da Antiguidade Clássica, no âmbito da Patristica. Mas não se pode esquecer as contribuições de Santo Tomás de Aquino, no período da Idade Média, juntos irão estabelecer o nexo entre pecado original e sexo. Esta compreensão atravessa a Cristandade Medieval, a Cristandade Moderna e assume novos contornos em Paulo VI no imaginário cristão no que tange a moral sexual. 
A crisma é o segundo sacramento e representa a confirmação do batismo (NUNES, 2008). Aspecto interiorizado pelo católico loca e que pode ser percebido no trecho abaixo:

Entrevistado 6: No sacramento da Crisma, então, ela é uma confirmação do batismo. Porque quando recebemos o Batismo éramos crianças e o questionamento é esse: criança, ela não sabe o que quer da vida dela [...].

Durante as observações desses dois sacramentos, ficou evidente que há uma predominância da ação gestual por parte de cada um dos indivíduos que integram o rito do batismo. Todavia, o principal gesto realizado é de responsabilidade do padre e consiste no cumprimento do sinal da Santíssima Trindade, em conjunto com a água derramada sobre a testa do batizando. De maneira geral, tal ação representa a incorporação daquele indivíduo à comunidade católica. Constatou-se também que há uma predominância da mão direita na realização da ação, fato que nos leva a retomar as discussões de Hertz (1980), referentes às inscrições do sagrado e do profano na lateralidade humana. Para Hertz (1980, p. 115), "na devoção, o homem procura acima de tudo comunicar-se com os poderes sagrados, de modo a mantê-los e a aumentá-los, e para trazer a ele os benefícios das ações destes poderes. Apenas a mão direita está apta para estas relações (...)".

Sobre o sinal da Santíssima Trindade, cumpre dizer que ele representa, para o católico local, a reprodução simbólica da cruz do Cristo histórico em seus corpos. Para que isso seja possível, a mão direita dos católicos deve percorrer quatro pontos específicos em seu corpo: a testa, a região torácica, o peitoral direito e o peitoral esquerdo. Esses quatro pontos geralmente são realizados concomitantemente com os dizeres "Em nome do Pai, do Filho e do Espírito Santo". Portanto, as principais representações assumidas por essa ação corporal estão relacionadas à invocação das três pessoas da Santíssima Trindade e a valorização do sacrifício da figura central da história do cristianismo: Jesus Crucificado. Isso explica o porquê de recriar uma cruz simbólica no corpo do vivente católico, pois a cruz representa o sacrifício, o amor, o sofrimento e a oferta do corpo de Jesus pela humanidade. Assim, quando os fiéis o realizam, reatualizam e reavivam, em sua cosmovisão, a mensagem e a vida de Cristo, fazendo do corpo, naquele instante, território para expressões do sagrado ${ }^{6}$.

O terceiro sacramento, o da Eucatistia, representa, com a crisma e o batismo, os sacramentos da iniciação cristã. No enredo católico, participar da Eucaristia tornou-se um fator primordial na busca pela comunhão com Cristo, pois é o corpo do Redentor simbolizado pela hóstia que nutre a vida humana. Por isso, a comunhão deve ser um dos primeiros deveres dos fiéis, uma vez que ela traz consigo as dimensões sacramentais, alimentares e escatológicas (GÉLIS, 2008). Desse modo, a hóstia passa a ser entendida como o eixo de mundos, ligando o mundo vivido e o mundo post mortem. Em outras palavras, quando o

6 Sobre o gesto do sinal da cruz cumpre dizer que, na tradição do Catolicismo Romano Latino Ocidental o mesmo se encerra no peitoral direito, enquanto que no Catolicismo Bizantino Grego Oriental finaliza-se no esquerdo. Essas diferenças gestuais devem analisadas de modo contextualizadas e inseridas no contexto litúrgico e dogmático do Campo da Patristica Grega Oriental, e da Patrística Latina Ocidental, que possui influencias Tertualianas e Agostianianas, cujo cerne tem como base a tradição da Escolástica Medieval. 
fiel assume o valor da salvação como caminho a ser percorrido, comungar representa uma das principais ações a serem cumpridas. Esses elementos podem ser mais bem averiguados na transcrição do seguinte trecho:

Entrevistado 4: Pra mim a comunhão é o corpo de Cristo, é o momento seu particular, com Deus. Você recebe a hóstia, que é o símbolo do corpo de Cristo, pra mim é isso.

Dito de outro modo, ao comungar, o fiel acredita que não come a hóstia nem bebe o vinho, mas alimenta seu corpo, seu espírito e a própria existência com cada um dos valores católicos: esses são os nutrientes indispensáveis para a manutenção do equilíbrio do viver humano católico. Meneses e Carneiro (1997) traçam o percurso histórico e humano das representações alimentares, apresentando diferentes discussões acerca da temática. No que se refere à religião, eles creditam a alimentação, representação singular na manutenção do domínio religioso presente nos Evangelhos e em suas metáforas, à Bíblia e, por fim, ao modo como o calendário litúrgico organiza o ciclo alimentar, com prescrições inclusive para com os jejuns.

Indo ao encontro do exposto, de acordo com Gélis (2008, p. 44), “o rito eucarístico é concebido para transformar pão, sempre e em toda parte, num único e mesmo corpo. O verbo encarnado é o alimento da alma". Desta maneira, por intermédio da hóstia, o fiel atinge estados, em sua cosmovisão, de proteção, sabedoria, paciência, perdão, amabilidade e sabedoria, para lidar com as inexatidões cotidianas. Isso pode ser observado nas transcrições abaixo:

Entrevistada 3: Então, cada vez que a gente comunga, é o corpo e o sangue de Cristo que está entrando em nossa vida. E vou te falar, quando eu comungo, me dá paz e força pra fazer tudo o que estou fazendo.

Entrevistado 6: $\mathrm{E}$ assim quando a gente alimenta do corpo e o sangue de Cristo a gente fica mais leve, a mente mais tranquila, então pra mim a comunhão, a eucaristia, o corpo e o sangue de Cristo é tudo em minha vida.

Esse sentimento representa para os católicos locais uma estrutura fundamental para a experiência com o sagrado: “a afirmação, pela igreja, da presença real do corpo de Cristo na hóstia durante o sacrifício da missa faz deste corpo o eixo do mundo. O fiel não tem esperança mais bela do que comer este corpo divino (...)" (GÉLIS, 2008, p. 48). Assim, o principal desdobramento da Eucaristia está na possibilidade de incorporação entre o corpo de Cristo e o corpo do cristão. Durante as entrevistas, houve pistas desse sentimento particular e íntimo do fiel para com a divindade.

Entrevistado 4: Pra mim a comunhão é o corpo de Cristo, é o momento seu particular, com Deus.

Entrevistado 5: Porque a Eucaristia é a representação de que Cristo veio aqui, e para que Cristo veio aqui, veio para salvar os pecadores. 
O sacramento eucarístico também deve estar ligado ao dia de Corpus Christi, "Manifestação das mais importantes no calendário católico e que tem por intuito ser o dia de celebração solene da transubstanciação do corpo de Deus" (MONTES, 1998). A própria celebração leva o corpo em seu nome, sendo a festa do corpo da figura central do catolicismo. Entre as corporeidades expressas ao longo da manifestação, estão as relacionadas ao trabalho de confecção do tapete. Observamos que, desde as $5 \mathrm{~h}$, as famílias se organizam ao longo do espaço que abrigará o percurso da procissão e iniciam os trabalhos de confecção. Outra observação diz respeito aos símbolos imagéticos confeccionados, tais como o cálice e a hóstia: eles são próprios da ocasião e têm por objetivo evidenciar que aquele momento representa o sacramento da Eucaristia e tudo o que a torna o elemento central do catolicismo.

Importa acrescentar que os desdobramentos desse caráter alimentar da fé são valores católicos que possuem denotação de privação e caráter penitencial. Eles também seriam legitimados na representação dos sofrimentos e dos momentos finais do Jesus histórico, que são difundidos e também são partes do sacramento eucarístico.

Para entender as representações da penitência, é preciso retomar o pressuposto de que um cosmo que pretenda legitimar-se e tornar-se plausível necessita que seus preceitos e valores sejam assimilados, incorporados e praticados. Por conseguinte, o catolicismo tem, em seu processo configuracional e estrutural, diferentes elementos e valores que o católico deve adotar. Perdão, castidade, caridade, temperança, honradez, amabilidade e bondade são exemplos desses valores, mas, quando o católico descumpre ou age na contramão de algum desses desígnios, outro valor católico entra em cena: o pecado. Desse modo, a própria cosmologia católica instituiu possibilidades de reverter tal condição: entre as ações possíveis, estão a confissão e os atos penitenciais, que representam a possibilidade do fiel demonstrar reconhecimento, arrependimento e vontade de reconciliar-se para obter a misericórdia divina (VATICAN, 2018). Por outro lado, esse preceito não deve ser visto como exclusivo para as referências ligadas à penitência: é imprescindível retomar também a valorização da representação do sofrimento na tradição cristã. Isso é devido principalmente, mas não exclusivamente, ao enredo que a tradição cristã apresenta, ligado à figura do Cristo, que sofreu todos os flagelos corporais, morais e psicológicos, além de ser crucificado, para que a humanidade fosse salva. Essa concepção é bastante difundida na cosmologia católica e, por conseguinte, se inscreve no imaginário popular, passando a acompanhar o cotidiano dos fiéis.

Em Brumal, foi possível averiguar elementos significativos referentes à questão da penitência com expressivas constituições corporais. A primeira menção registrada aconteceu durante as observações de carnaval. Um morador, em momento informal com outros moradores, revelou que permaneceria o período da Quaresma sem fazer uso de bebida alcoólica. Neste caso, nota-se que, ao partilhar de tal valor, ele priva seu corpo de um de seus prazeres, representado pelo consumo de bebida alcoólica. Comprova, assim, a essência da penitência, o de privar o indivíduo de práticas cotidianas que o proporcionem prazer e, consequentemente, valorizar a representação do sofrimento com nítido desdobramento para o corpo do fiel. Outras nuances podem ser percebidas nos trechos a seguir: 
Entrevistada 2: As minhas penitências, ás vezes me privo de alguma coisa. Olha! Eu tô agora fazendo pra São José. No dia de São José, eu coloco aquele tanto de frutas e sorteio uma fruta e não como durante um ano.

Entrevistado 5: Eu faço o jejum o dia inteiro, tanto na quinta-feira quanto na sexta-feira, se eu conseguir, igual quando eu trabalho de manhã, se eu conseguir sair só com um copo d'água melhor.

Para Gélis (2008, p. 56), “a privação alimentar é a punição mais imediata que se faz ao próprio corpo. Os relatos hagiográficos testemunham, aliás, a grande variedade dessas privações $[\ldots]^{\prime \prime}$.

Em nossos registros, uma das moradoras relatou que era prática rotineira seus pais realizarem jejuns de um dia inteiro na Sexta-Feira da Paixão e acrescentou que não comiam carnes durante toda a Quaresma e eles a impediam de brincar, arrumar a casa e até mesmo pentear o cabelo nesse dia. A propósito disso, é possível elevar a privação alimentar a um patamar que envolve valores da cosmologia católica considerados coerentes e necessários para aquele sistema: é nítido que esse privar-se extrapola os níveis puramente alimentares. Um dos argumentos de maior difusão está na comparação entre as nuances das penitências realizadas pelos católicos e o quadro de sofrimento ao qual Jesus, da tradição católica, foi submetido, criando outro nível de busca pela incorporação a ele pela reatualização de seus flagelos, dores e sofrimento.

Gélis (2008) enfatiza que essa busca se dá principalmente pela compreensão e difusão do sofrimento como valor católico, que se expressa nos corpos dos fiéis. Em outras palavras, quando o fiel estabelece comparações entre o seu jejuar penitente e o jejuar forçado de Jesus, ele almeja reatualizar aquele estado, para retribuir e agradecer as ações da divindade em sua vida, valorizando e aceitando aquele instante de sofrimento. Isso é devido à aspiração de assemelhar-se ao sofrimento de Cristo, que tem o corpo como maior obstáculo e inimigo a ser vencido, mas o tem também como o principal meio para atingir tal estado. Em conversas com os moradores, era bastante comum ouvir expressões como: "Se Jesus sofreu assim, porque eu não posso?"; ou "Jesus foi crucificado e sofreu bem mais do que estou sofrendo". Essas expressões verbais sugerem a valorização do ato penitencial, que se associa à necessidade que o fiel católico tem de incorporar sua relação com Cristo.

As observações realizadas durante a Semana Santa em Brumal fornecem informações suficientes para que se possa conferir à Sexta-Feira da Paixão a condição de ser o dia do calendário religioso dedicado à valorização das representações penitenciais e de sofrimento. Indubitavelmente, nesse dia Brumal é tomado por uma aura de recolhimento e tristeza. Não são vistas crianças brincando; os bares e o comércio em geral permanecem de portas fechadas; não se ouve música alta; e, praticamente, não há transeuntes nas ruas. O ápice das expressões do sofrimento católico ocorre durante a manifestação denominada via-sacra, ou via-crúcis, caminho da cruz. Essa procissão solene, de caráter penitencial, tem por objetivo representar e reatulizar os 14 ou 15 momentos de que conta a tradição cristã referentes ao caminho percorrido por Jesus, desde seu julgamento até o Calvário onde é crucificado (NUNES, 2008). Corbin (2004) acrescenta a isso que a via-sacra representa, 
em cada uma de suas estações, a possibilidade de o fiel lembrar e reviver o sofrimento progressivo do corpo de Cristo.

Quando avançamos a pesquisa para o sacramento do matrimônio, popularmente conhecido como casamento, averigua-se que ele representa a aliança estabelecida entre homens e mulheres sob a égide católica. Ao longo da história cristã, verificaram-se mudanças significativas nos valores matrimoniais. Entretanto, a mais significativa para a pesquisa diz respeito ao ato sexual, uma vez que, na cosmologia católica, homens e mulheres, ao casarem-se, prometem o uso sexual de seus corpos somente para a procriação, e não para a satisfação prazerosa advinda de momentos de volúpia (NUNES, 2008; CORBIN, 2004). Isso remete ao caráter monástico e a condição de castidade que o casamento exige, segundo o entendimento de como deva ser a vida sexual do casal segundo os preceitos católicos (LE GOFF, 1994). Com isso, os deveres conjugais assumiram representações ímpares de controle das necessidades sexuais de homens e mulheres. No entanto, a Igreja se vê diante de um quadro complexo referente aos níveis de proibição estabelecidos. Reconhecendo os riscos de estabelecer um quadro de reclusão muito severo, considerou melhor que o casal se entregasse às vontades de um e do outro do que cometessem adultérios, prostituições e promiscuidades (CORBIN, 2004). A partir disso, desenvolveu-se um quadro de negociações sobre os sentidos da castidade, tendo, de um lado, a religião e o controle da sexualidade e, de outro, as necessidades sexuais humanas. O trecho a seguir contribui para o entendimento quanto ao modo como esses valores são interalizados pelo vivente católico local:

Entrevistado 6: Eu entendo que castidade também é fidelidade no casamento. Por exemplo, um casal sendo fiel, ele também tá sendo casto também.

Sobre o sentimento de culpa presente nas referências sexuais, Le Goff (1994) e Corbin (2004) consideram que as mudanças religiosas para a questão sexual fizeram com que esse sentimento tivesse presença constante no vivente cristão. O mesmo Corbin (2004) enfatiza as referências relacionadas à virgindade como valor católico, o que somente é possível devido à valorização da figura da Virgem Maria, que, mesmo sendo mãe, preservou sua virgindade, pois ,em seu ventre, estava o Salvador. Com isso, somadas ao elemento salvação, a virgindade e a consequente castidade assumem, ao longo da história católica, valores e singularidades que permeiam, de maneira substancial, a cosmovisão e a maneira de o católico viver a própria sexualidade.

Entrevistada 3: A questão da castidade foi por opção mesmo. Hoje eu acho uma bobagem e não incentivo ninguém. Acho que a gente precisa ter experiência, com seu próprio marido.

Entrevistado 5: Na Igreja hoje, graças a Deus, os padres também estão com a cabeça voltada pra realidade do nosso mundo, então eles trabalham em cima disso, não apoiando o sexo em geral, abolindo a prostituição, as orgias.

Por fim, se o batismo representa a entrada do indivíduo no cosmo católico, a unção dos enfermos inclui entre suas funções a de representar a passagem final do caminho para a 
salvação. Para Rodrigues (2006), nascimento e morte são as duas transformações singulares que o ser humano sofre ao longo das múltiplas modificações vividas ao longo do ciclo vital. Nessa categoria, o desdobramento que se destaca é o referente às representações católicas da morte e do morrer. O morrer católico é legitimado, principalmente por meio do valor da salvação, conforme apresenta Gélis (2008, p. 91): “Essa mutação do espaço da morte, que corresponde a uma transformação profunda e progressiva da consciência da vida, vem acompanhada de novos costumes [...]". Assim, a vida católica destaca-se por uma dualidade interacional, ou seja, o fiel deve viver de acordo com a cosmologia católica, para que, ao morrer, atinja um novo modo de ser e alcance a salvação. Do mesmo modo, essa mudança está associada a outros espaços de vida: o paraíso, o purgatório e o inferno (BRANDÃO, 1986). O trecho abaixo confirma como esses valores permeiam o imaginário do católico local.

Entrevistada 1: Na verdade nem é morte, pra mim. Salvação, eu acho que você alcança ela depois que você arrepende das coisas ruins, que você fez, aí você atinge a salvação, pra mim é isso. Essa salvação você vai estar mais perto de Jesus e vai ser perdoado de tudo que você fez.

Migliori (2009), em sua dissertação sobre as representações da morte, constata que o sacramento em questão assumiu novas peculiaridades no Concílio Vaticano II. Se outrora esse sacramento era concedido aos católicos em estado terminal de vida, fornecendo-lhes conforto, ao oferecer aos moribundos o perdão por possíveis falhas, e ajudando-os na perspectiva de alcance da salvação, posteriormente ele sofreria mudanças estruturais importantes, entre as quais a alteração de sua nomenclatura, pois deixou de ser denominado extrema-unção para ser designado unção dos enfermos. Essa alteração linguística visou a dissociar tal sacramento de uma série de questões relativas à morte e ao morrer. Principalmente, e não exclusivamente, libertar os fiéis de um possível estado de condenação que alguns deles sofreriam no pós-morte.

O sacramento agora denominado unção dos enfermos passa a ter novas representações e funções no interior da cosmologia católica, por supor a possibilidade de contribuir para o resgate da saúde do enfermo. Isso determina a ocorrência de um destaque corporal significativo, pois a perda da saúde, na maioria dos casos, acha-se relacionada a questões corporais. Atualmente esse sacramento dirigido à comunidade de Brumal está associado a uma missa também dedicada à recuperação da saúde, celebrada exatamente na terça-feira da Semana Santa. Dedicada aos doentes da comunidade, essa missa tem por objetivo central orar pela restauração da saúde dos fiéis da localidade. Nessa celebração, as representações corporais observadas mostram-se atreladas ao objetivo de curar por intermédio do sagrado, objetivo esse que é claramente explicitado pelo padre: "Não se trata de patuá, nem de magia, e sim da ação sacramental de Deus". O rito representa para os indivíduos doentes e para os idosos da comunidade a esperança de recuperação da saúde e de prolongamento da condição saudável.

Os ritos mortuários em Brumal não ficam restritos à categoria de costumeiros, pois também podem ser identificados atualmente como práticas clericalizadas, com a 
igreja gerenciando as ocorrências do momento e fornecendo liturgia adequada, missas e orações específicas para a ocasião (RODRIGUES, 2008). Essas ações recebem o nome de exéquias e transcorrem nos espaços por onde o corpo do falecido será conduzido, o que, na maioria das vezes, inclui o local do velório, o templo oficial e o cemitério (NUNES, 2008). Tais procedimentos substituíram a condição doméstica das práticas mortuárias de outrora em Brumal.

Para Elias (2001, p. 7), “há várias maneiras de lidar com o fato de que todas as vidas, inclusive a das pessoas que amamos, têm um fim. O fim da vida que chamamos de morte, pode ser mitologizado pela ideia do Hades ou no Valhalla, no Inferno ou Paraíso". Segundo Nascimento (2006, p.169), "a morte constitui um momento-chave para qualquer grupo social; é inevitável, por outra parte, que ela assuma diferentes significados em diferentes momentos históricos". Já Berger (1985) considera a morte um fenômeno anomizante por ameaçar constantemente as estruturas de plausibilidade e legitimação, fragilizando a coesão do nomos estabelecido socialmente. Nesse sentido, o catolicismo apresenta também uma maneira de lidar com as questões que permeiam o morrer humano.

Segundo essa perspectiva, e dirigindo as reflexões para as particularidades que cercam o morrer católico em Brumal, é possível destacar o ritual do velório, a missa de corpo presente, o enterro e o dia de finados. O primeiro representa o ritual de passagem e marca a saída de um modo de ser aqui na terra para outro modo de ser no além-túmulo. Em outras palavras, representa a última passagem do caminho que todo católico acredita percorrer para alcançar a salvação e a ressurreição. Esses rituais funerários caracterizam-se também por serem ocasiões em que familiares e amigos se reúnem para orar, compartilhar emoções e prestar homenagens ao falecido. O dia de finados é dedicado à realização de visitas aos túmulos dos mortos, com a finalidade principal de relembrar os que se foram, render-Ihes homenagens e orar por eles. Durante sua estada no cemitério, os visitantes realizam limpeza de túmulos, arrumam flores em vasos, oram e buscam comunicar-se, de maneira particular, e às vezes comovente, com aqueles que morreram, cujo desdobramento corporal se faz por meio da representação imagética das estruturas biofísicas que compunham aquele sujeito em vida.

A morte, parte inerente da existência humana, é, no dizer de Elias (2001, p. 19), "um dos grandes perigos biossociais da vida humana". A sua representação no cosmo católico, sob a estrutura sacramental, que interessa ao nosso estudo, acha-se relacionada às vicissitudes singulares que trazem consigo as questões corporais. A primeira perspectiva que se apresenta é a da morte como marco de saída do viver biofisiológico. A segunda, diretamente imbricada à primeira, é referente à percepção da morte não como final do existir humano, mas como nova transformação que o indivíduo católico almeja alcançar ao morrer, ao deixar o corpo. A esses dois parâmetros devem-se as representações construídas pelo catolicismo, que articulam os elementos salvação e ressurreição às outras estruturas de seu enredo. Assim, a representação de morte no catolicismo assume uma função singular na sustentação das estruturas de plausibilidade e legitimação no que se refere à orientação da vida dos fiéis, pois abre a possibilidade, na cosmovisão católica, de superar a aparente finitude humana. 


\section{CONCLUSÕES}

Ao fim desse enveredamento científico, é possível sinalizar que é imprescindivel para a Educação Física, cujos estudos sobre as práticas corporais inseridas no contexto da cultura corporal de movimento têm sido intensificados, ampliar as discussões sobre as nuances corporais, uma vez que o corpo pode ser compreendido como o "primeiro e mais natural objeto técnico, e ao mesmo tempo, meio técnico do homem, seu corpo" (MAUSS, 1974 , p. 217). Também esperamos ter respondido aos desafios propostos por Mauss (1974), ao abordarmos o corpo como objeto de estudo da sociologia, agora não mais incluído na categoria de "diversos". Sobre a questão do estudo, constatou-se que as corporeidades constituídas por tal solução sacral estão associadas aos sacramentos que são os principais elementos responsáveis pela difusão do catolicismo e pela organização da experiência individual e coletiva daqueles que escolheram tal expressão religiosa. Com destaque para a Eucaristia, sacramento central do catolicismo, bem como as suas representações, que se acha associada e interligada aos demais sacramentos. Esse sacramento é responsável pela difusão de centralidade e tem por eixo base a figura do Jesus histórico, fundamento da cosmologia católica que se desdobra para as nuances corporais em instâncias sacramentais, alimentares e escatológicas.

\section{REFERÊNCIAS}

ALBUQUERQUE, Leila Marrach Basto de. As invenções do corpo: modernidade e contramodernidade. Motriz, v. 7, n. 1, p. 33-39, jun. 2001.

ANGLOGOLD. Estudo de impacto ambiental - ElA: projeto sulfetado mina Córrego do Sítio 1. Santa Bárbara - MG, v. 1. Belo Horizonte, 2009.

BERGER, Peter Ludwig. O dossel sagrado: elementos para uma teoria sociológica da religião. São Paulo: Paulus, 1985.

BETTI, Mauro. Educação Física e sociedade. São Paulo: Movimento, 1991.

BOURDIEU, Pierre. Coisas ditas. São Paulo: Brasiliense, 2004.

BRANDÃO, Carlos Rodrigues. Os deuses do povo: um estudo sobre a religião popular. 2. ed. São Paulo: Brasiliense, 1986.

CAMARGO, Candido Procopio Ferreira de. Católicos, protestantes, espíritas. Petrópolis: Vozes, 1973.

CASTANEDA, Carlos. A erva do diabo: as experiências indígenas com plantas alucinógenas reveladas por Don Juan. 12. ed. São Paulo: Record, 1968.

SOARES, Carmen et al. Metodologia do ensino da Educação Física. São Paulo: Cortez, 1992.

CORBIN, Alain. A influência da Religião. In: CORBIN, Alain; COURTINE, Jean Jacques; VIGARELLO, George. (Dirs.). História do corpo: da revolução à grande guerra, v. 2. Petrópolis: Vozes, 2008.

CURATO NOSSA SENHORA DAS GRAÇAS. Planejamento pastoral 2011. Brumal, 2011.

DA MATTA, Roberto. O ofício do etnólogo, ou como ter Anthropological Blues. In: NUNES, 
julho/2018

Edson Oliveira (Org.). A aventura sociológica: objetividade, paixão, improviso e método na pesquisa social. Rio de Janeiro: Zahar, 1978.

DAOLIO, Jocimar. Os significados do corpo na cultura e as implicações para a Educação

Física. Revista Movimento, ano 2, n. 2, jun. 1995.

DAOLIO, Jocimar. Da cultura do corpo. Campinas: Papirus, 2004.

ELIADE, Mircea. O sagrado e o profano. São Paulo: Martins Fontes, 1992.

ELIAS, Norbert. A sociedade dos indivíduos. Rio de Janeiro: Jorge Zahar, 1994.

ELIAS, Norbert. A solidão dos moribundos: seguido de envelhecer e morrer. Rio de Janeiro: Jorge Zahar, 2001.

GÉLIS, Jacques. O corpo, a igreja e o sagrado. In: CORBIN, Alain; COURTINE, Jean Jacques. VIGARELLO, Georges. (Dirs.). História do corpo: da Renascença às Luzes, v. 1. Petrópolis: Vozes, 2008.

HERTZ, Robert. A preeminência da mão direita: um estudo sobre a polaridade religiosa.

Revista Religião e Sociedade. Rio de Janeiro: Tempo e Renascença, n. 6, p. 99-128, 1980.

JOVCHELOVITCH, Sandra; BAUER, Martin. W. Entrevista Narrativa. In: BAUER, Martin.; GASKELL, George. Pesquisa qualitativa com texto, imagem e som. Petrópolis: Vozes, 2002, p. 90-113.

LE BRETON, David. A Sociologia do corpo. Petrópolis: Vozes, 2007. LE GOFF, J. O imaginário medieval. Portugal: Estampa, 1994.

MAUÉS, Raymundo Heraldo. Algumas técnicas corporais na Renovação Carismática

Católica. Ciências Sociales y Religión/Ciências Sociais e Religião, Porto Alegre, ano 2, n. s, p. 119-151, 2000.

MAUSS, Marcel. As Técnicas Corporais. In: Sociologia e Antropologia. São Paulo: EPU/ EDUSP, 1974.

MENESES, Ulpiano Toledo Bezerra de.; CARNEIRO, Henrique. A história da alimentação: balizas historiográficas. Anais do Museu Paulista. São Paulo, N. Sér. v. 5, p. 9-91, 1997. MONTES, Maria Lucia. As figuras do sagrado: entre o público e o privado. In: NOVAIS, Fernando (Coord.). História da vida privada no Brasil. São Paulo: Companhia das Letras, 1998.

MIGLIORI, Rogerio Costa. Corpos mortos e vivos: as cerimônias mortuárias e as representações da morte entre católicos brasileiros. Dissertação - Programa de PósGraduação em Ciências da Religião. Faculdade de Filosofia e Ciências da Religião, Universidade Metodista de São Paulo, 2009.

MILLS, Charles Wright. A imaginação sociológica. Waltensir Dutra (Trad.). Rio de Janeiro: Zahar, 1975.

NUNES, Veronica Maria Meneses. Glossário de termos sobre religiosidade. Aracaju: Tribunal de Justiça/Arquivo Judiciário do Estado de Sergipe, 2008.

RODRIGUES, Claudia. A arte de bem morrer no Rio de Janeiro setecentista. Varia Historia, Belo Horizonte, v. 24, n. 39, p. 255-272, 2008.

RODRIGUES, José Carlos. Tabu do corpo. Rio de Janeiro: Fiocruz, 2006.

SANT'ANNA, Denise. Bernuzzi. É possível realizar uma história do corpo? In: SOARES.

C. (Org.). Corpo e história associados, 2001. Campinas: Autores. 
VATICAN. Os sete sacramentos da igreja: capitulo segundo, os sacramentos de cura. Disponível em: < http://www.vatican.va/archive/cathechism_po/index_new/ p2s2cap1_1420-1532_po.html > Acesso em: 05 de Junho de 2018.

VELHO, Gilberto. Observando o familiar. In: NUNES, Edson Oliveira. (Org.). A aventura sociológica: objetividade, paixão, improviso e método na pesquisa social. Rio de Janeiro: Zahar, 1978.

Recebido em: Maio/2017

Aprovado em: Junho/2018 